Robin Böttjer1, Jan Lukas Storck', Dominik Vahle'1, Bennet Brockhagen'1, Timo Grothe', Sabine Herbst'1, Karl-Josef Dietz², Anke Rattenholl1', Frank Gudermann'1, Andrea Ehrmann ${ }^{1}$

1 Bielefeld University of Applied Sciences, Faculty of Engineering and Mathematics, Interaktion 1, 33619 Bielefeld, Germany

2Bielefeld University, Biochemistry and Physiology of Plants, 33501 Bielefeld, Germany

\title{
Influence of Textile and Environmental Parameters on Plant Growth on Vertically Mounted Knitted Fabrics
} Vpliv tekstilnih in okoljskih parametrov na rast rastlin $v$ navpično nameščenih pletivih

\author{
Original Scientific Article/lzvirni znanstveni članek
}

Received/Prispelo 7-2019• Accepted/Sprejeto 8-2019

\begin{abstract}
Vertical farming is of major interest in research and development to enable the production of food in the quantity sufficient for the growing world population under the weather conditions, which are increasingly becoming more and more extreme. Especially in cities, vertical farming allows for growing vegetables and other plants locally. Apart from industrial applications of vertical farming, new ideas are being developed to make cities "greener", often related to the maker culture. In the study, we concentrated on the second approach by investigating the possibilities to grow plants on textile fabrics placed vertically, e.g. along a balcony railing, but also as structural elements in agricultural areas. Our investigations revealed, using the example of cress, that steadily irrigated knitted fabrics enable plant growth on them, indicating no significant differences between differently knitted stitch dimensions and different illumination intensities. Finally, we discuss the possibilities to measure the time-resolved plant growth reliably and suggest additional possibilities to evaluate the growth success.

Keywords: vertical farming, textile fabrics, plant growth, knitted fabrics, hydroponics, measurement technology, cress, illumination, irrigation
\end{abstract}

\section{Izvleček}

Vertikalno kmetovanje je zelo pomembno za raziskave in razvoj, saj omogoča pridelavo dovolj hrane za rastoče svetovno prebivalstvo $v$ čedalje bolj ekstremnih vremenskih razmerah. Zlasti v mestih omogoča vertikalno kmetovanje lokalno pridelavo zelenjave in drugih rastlin. Poleg teh industrijskih aplikacij vertikalnega kmetovanja se razvijajo nove ideje za ozelenitev mest, ki so pogosto povezane s kulturo pridelovalcev. Članek se osredotoči na drugačen pristop z raziskovanjem možnosti gojenja rastlin na ploskovnih tekstilijah, postavljenih navpično, npr. ob balkonski ograji, pa tudi kot strukturni elementi na kmetijskih območjih. Naše raziskave na primeru kreše kažejo, da stalno namakanje pletiva omogoča rast rastlin na njih, pri čemer ni pomembnih razlik med različnimi dimenzijami zank pletiv ter različnimi intenzivnostmi osvetlitve. Na koncu je podana razprava o možnostih zanesljivega merjenja rasti rastlin in predlagane so dodatne možnosti za oceno uspeha rasti.

Ključne besede: vertikalno kmetovanje, ploskovne tekstilije, rast rastlin, pletiva, hidroponika, merilna tehnologija, kreša, osvetlitev, namakanje

Corresponding author/Korespondenčna avtorica:

Prof. Dr. Dr. Andrea Ehrmann

E-mail: andrea.ehrmann@fh-bielefeld
Tekstilec, 2019, 62(3), 200-207

DOI: 10.14502/Tekstilec2019.62.200-207 


\section{Introduction}

Textile fabrics are applied in diverse areas, from garments and home textiles to a broad range of technical textiles. In agriculture, woven fabrics, warp or weft knitted fabrics can often be found [1], typically produced from polyester, polyamide [1], polyethylene $[2,3]$ or other man-made fibres. These technical textiles can protect early outdoor plants from harsh environmental conditions and herbivores $[4,5]$, from contaminations [6-8] etc.

In spite of the frequent use of textile fabrics in agriculture, there are not many reports in the literature on letting plants grow on textile substrates [9]. Recently, our group investigated the growth of Pleurotus ostreatus mycelium on nanofibre mats [10] and knitted fabrics [11], respectively, as well as microalgae growth on nanofibre mats [12]. In this study, the growth of higher plants on weft knitted fabrics was investigated to enable plant growth on vertically positioned substrates for the application in vertical farming.

The developed method can be defined as a combination of hydroponics - where plants are grown in water supplemented with macro- and micro-nutrients - and aeroponics - where plants are grown in humid air or water vapour without a water reservoir [13]. Generally, the main aim of vertical farming is to grow plants with increased yield per unit area [14]. This is especially important in large cities where not enough agricultural areas are available to deliver food for the local population [15]. The socalled farmscrapers may offer an alternative to long transport distances [16]. Due to the possibility of recycling the necessary water, to avoid biocides and reduce transport energy, vertical farming can be even more sustainable than conventional farming, besides avoiding the growing danger of extreme weather events [17].

While "vertical" in the case of such farmscrapers is usually defined as vertically stacked horizontal reservoirs of water with nutrients in which plants are growing, vertically positioned substrates for plant growth are only sometimes used by makers and hobby gardeners. However, the latter has not yet been reported in the scientific literature. Therefore, in this paper, we give the first overview of the influence of different environmental factors and substrate parameters on plant growth, serving as the base for future experiments on vertical farming in the literal sense. We thus mostly aim at suggesting possible substrates for makers and others who want to use as much of their balcony or other small spaces to grow flowering plants, herbs, moss or other plants, making their environment "greener" etc.

\section{Materials and methods}

Single-jersey fabrics of dimensions $5 \mathrm{~cm} \times 5 \mathrm{~cm}$ were knitted on a hand flat knitting machine Silver Reed SK 280 (Knittax, Darmstadt, Germany) with needle gauge E5.6 (i.e. needle distance $4.5 \mathrm{~mm}$ ), using the stitch dimension settings 3,5 , and 7 , which were found well knittable. Polyacrylonitrile (PAN) yarn of 45.5 tex $\times 2(\mathrm{Nm} 22 / 2)$ (Andreas Hoffmann Garnhandel \& Textilspulerei, Engstingen, Germany) was used to enable a comparison with previous experiments dealing with micro-algae [12] or mushroom mycelium [10] on PAN nanofibre mats. Furthermore, pre-experiments revealed the hydrophilic, hygroscopic properties of knitted fabrics from PAN, while some other materials showed reduced water transport abilities. Finally, this material was chosen to create the test environment with long-time stability, opposite to for example jute or wool, both of which were found to be more prone to mildew and rotting under continuously wet conditions. The fabrics used, however, did not change their mechanical properties significantly during the study, making them re-usable for a sustainable setup.

Table 1 gives an overview of knitted fabric parameters. Thickness was measured using a digital gauge J-40-T (Wolf-Messtechnik GmbH, Freiberg, Germany) and areal weight with an analytical balance SE202 (VWR International GmbH, Darmstadt, Germany). The microscopic images to distinguish the course and wale densities were taken with a digital

Table 1: Parameters of knitted fabrics used in this study $(n=3)$

\begin{tabular}{|l|c|c|c|}
\hline \multirow{2}{*}{\multicolumn{1}{|c|}{ Parameter }} & \multicolumn{3}{c|}{ Stitch size } \\
\cline { 2 - 4 } & 3 & 5 & 7 \\
\hline Thickness $[\mathrm{mm}]$ & 1.78 & 1.82 & 1.85 \\
\hline Areal weight $\left[\mathrm{g} / \mathrm{m}^{2}\right]$ & 211 & 196 & 181 \\
\hline Apparent density $\left[\mathrm{kg} / \mathrm{m}^{3}\right]$ & 118 & 107 & 98 \\
\hline Stitch length $[\mathrm{mm}]$ & 10.3 & 12.0 & 13.7 \\
\hline Course density $\left[\mathrm{cm}^{-1}\right]$ & 5.1 & 4.4 & 3.7 \\
\hline Wale density $\left[\mathrm{cm}^{-1}\right]$ & 4.6 & 4.4 & 4.1 \\
\hline
\end{tabular}


microscope VHX-600K (Keyence, Neu-Isenburg, Germany).

The sample borders were seamed to avoid the unravelling of fabrics. Then, all samples were handcoated with Konjac Gum Powder (Special Ingredients, Chesterfield, UK) solution (2 g Konjac Gum Powder dissolved in $240 \mathrm{ml}$ deionized water) with the aid of a doctor blade. This method was found more accurate than common rolling knives, boxtype doctor knives or a foulard. Konjac Gum Powder contains konjac glucomannan, a polysaccharide extracted from Amorphophallus konjac [18] with high water binding and gelation abilities and is typically used in the food industry [19].

Using this polysaccharide is a compromise between using fully biodegradable fabrics - which would work very well when thinking about using the fabric to position the seed only for a limited time, e.g. when placing it on a steep slope where the plants should fix the ground - and using a fully stable fabric. The latter is necessary here or the seeds would lose their footing if the fabrics degraded. The biodegradable Konjac Gum Powder dissolves with time so that the seeds can germinate without problems, while the time-stable PAN forms the base in which the roots can be fixed.

Immediately afterwards, 9 cress seeds (Lepidium sativum L., Kiepenkerl, Everswinkel, Germany) per sample were placed in a matrix of $3 \times 3$ seeds with similar distances on a wet coating and thus glued to the fabric. Afterwards, the coating was dried in air at room temperature for $2 \mathrm{~h}$, before the samples were fixed on the vertical test stand.

The sketch and image of the test stand $(45 \mathrm{~cm}$ high, $180 \mathrm{~cm}$ long) are presented in Figure 1. The textile fabrics were mounted on the metal grid visible in Figure 1 (left panel). Each column of samples was irrigated constantly with supply water (water hardness level $16^{\circ}$ d, i.e. 16 degrees of hardness or "hard" water), using a pump INDOOR P300-i (Heissner, Lauterbach, Germany) with the power of $3.6 \mathrm{~W}$, positioned in a water reservoir below the samples, pumping the water constantly from the reservoir into the upper tube (black half-tube). The measurement results of the spatially resolved flow rate for different columns are given in Results and Discussion. Additional nutrients were not used since only the germination process was examined and no nutrient supply is necessary for it.

For illumination, 2 LED tubes "TubeKIT LED $1.5 \mathrm{~m}$ 21.5W/830" (Osram, Munich, Germany) with $150 \mathrm{~cm}$ in length with the colour temperature of $3000 \mathrm{~K}$, $21.5 \mathrm{~W}$ power, $150^{\circ}$ angle of irradiation and $1890 \mathrm{~lm}$ luminous flux were used for $16 \mathrm{~h}$ per day. They were positioned horizontally in front of the test stand (not visible in Figure 1). The spatially resolved light intensity measurements, performed with a solarimeter KIMO SL-200 at the positions of samples, are given in Results and Discussion.

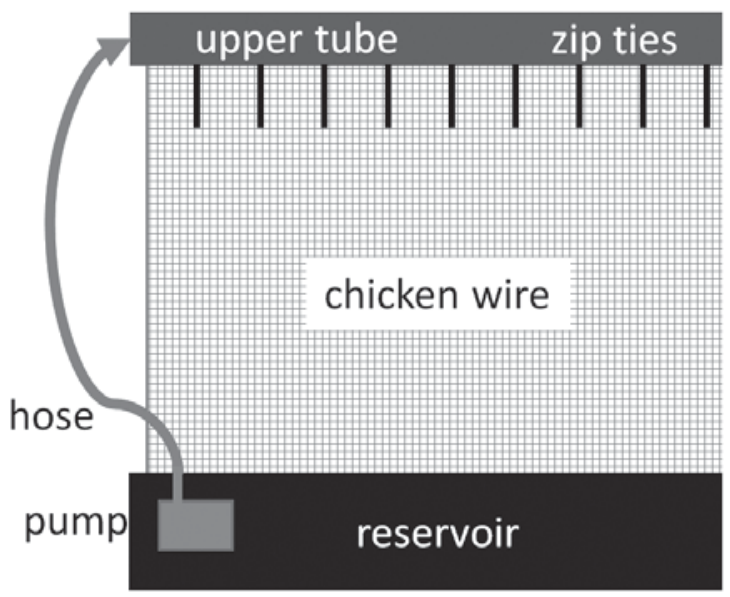

a)

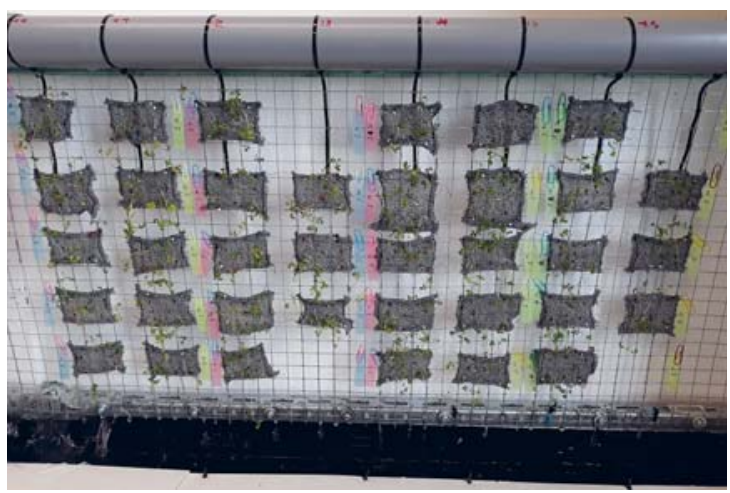

b)

Figure 1: Vertical test stand: a) sketch of left part (columns 1-9 in Figure 2) of vertical test stand with pump inside water reservoir and zip ties as flow direction control; b) real test stand (columns 10-17 in Figure 2) with knitted fabrics and cress growing on samples

The arrangement of samples on the test stand is depicted in Figure 2. It allows for comparing different stitch dimensions of knitted fabrics (cf. colour codes), different light intensities and irrigations, in this way enabling the evaluation of the influence of these three parameters. The free fields (white in colour) are used as indicators to support a fast orientation among sample positions. 


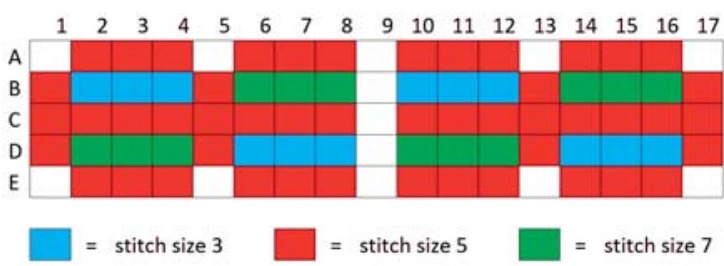

Figure 2: Arrangement of samples with different stitch sizes on vertical test stand and numbering of sample positions

During the experiments, the relative humidity in a not air-conditioned laboratory varied between 35\% and $50 \%$, while the temperature varied between $20.6{ }^{\circ} \mathrm{C}$ and $23.1^{\circ} \mathrm{C}$. The plant growth was examined for 27 days, starting with the measurements 2 days after placing the seeds on the textile fabrics. Plant lengths were measured using sliding callipers, measuring the distance between the fixing point in the fabric and end point without stretching the plant to avoid any possible disturbance and damage. To evaluate this measurement method, on the last day of experiments, all plants were cut directly above the textile fabric, stretched and in this state glued on a sheet of paper for measuring.

\section{Results and discussion}

Figure 3 shows the measurements of illumination per sample position, given in $\mathrm{W} / \mathrm{m}^{2}$. Firstly, it must be mentioned that these values are low, as compared to sunlight, which can reach up to $700 \mathrm{~W} / \mathrm{m}^{2}$ in the summer and up to $250 \mathrm{~W} / \mathrm{m}^{2}$ in the winter in the middle Europe, but correspond approximately to typical light intensities in offices and other rooms [20]. Next, it is also visible that the light intensities vary strongly between different sample positions. In this way, the evaluation of the influence of the light intensity is possible. The flow rate through each of the 17 holes is depicted in Figure $4(n=3)$. Apparently, a few of these holes do not work properly (nos. 1, 4, 14). Nevertheless, the variations of the flow rate enable the estimation of the influence of this factor.

\begin{tabular}{c|c|c|c|c|c|c|c|c|c|c|c|c|c|c|c|c|c|c|}
\multicolumn{1}{c}{} & \multicolumn{1}{c|}{} & 2 & 3 & 4 & 5 & 6 & 7 & 8 & 9 & 10 & 11 & 12 & 13 & 14 & 15 & 16 & 17 \\
\hline & 5 & 7 & 9 & 10 & 10 & 10 & 10 & 10 & 10 & 10 & 10 & 9 & 9 & 6 & 5 & 4 & 2 \\
\hline B & 5 & 7 & 9 & 10 & 10 & 10 & 10 & 10 & 10 & 10 & 11 & 9 & 9 & 7 & 6 & 4 & 2 \\
\hline C & 5 & 7 & 8 & 9 & 10 & 10 & 10 & 10 & 10 & 11 & 10 & 8 & 9 & 6 & 6 & 4 & 2 \\
\hline D & 5 & 6 & 8 & 8 & 8 & 8 & 8 & 10 & 9 & 10 & 9 & 8 & 8 & 6 & 6 & 3 & 3 \\
\hline
\end{tabular}

Figure 3: Illumination in $\mathrm{W} / \mathrm{m}^{2}$, measured in middle of each sample position

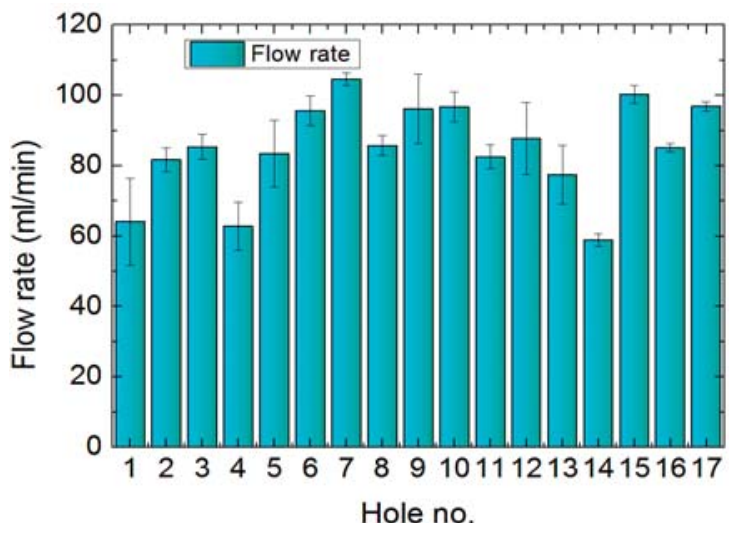

Figure 4: Flow rate, measured per irrigation hole

The Konjac Gum Powder used to glue seeds on textile fabrics is not long-time water-resistant, i.e. it starts swelling when exposed to water, and enables contact between seeds and water as well as growing of roots of germinating cress through the konjac coating. This may, on the other hand, be problematic if the coating is dissolved faster than the root can anchor itself in the knitted fabric. This effect is depicted in Figure 5, where the numbers of lost seeds are given.

It should be mentioned that no correlation is apparent with either the flow rate (cf. Figure 4) or illumination (cf. Figure 3), indicating that the seed positioning should be improved, e.g. by pressing the seed deeper into the konjac coating. However, the number of established seedlings cannot be improved by modifying the longevity of the coating, which would be the case if slow-growing seeds were disadvantaged. This conclusion is supported by the finding that indeed most seeds were lost during the first few days of the experiment, before any seedling managed to stabilize its roots inside the knitted fabric.

Another important factor is the total amount of seedlings which developed further to a plant. Figure 6 shows the number of seeds which did not start growing. Interestingly, these numbers are clearly not correlated with the flow rate (cf. Figure 4), otherwise large numbers of dormant seeds would be expected in columns 1,4 and 14 .

\begin{tabular}{|l|l|l|l|l|l|l|l|l|l|l|l|l|l|l|l|l|}
1 & 2 & 3 & 4 & 5 & 6 & 7 & 8 & 9 & 10 & 11 & 12 & 13 & 14 & 15 & 16 & 17 \\
\hline & 0 & 2 & 2 & & 3 & 1 & 1 & & 1 & 2 & 3 & & 2 & 2 & 1 & \\
\hline 1 & 3 & 1 & 1 & 2 & 1 & 1 & 2 & & 0 & 2 & 1 & 1 & 1 & 0 & 0 & 1 \\
\hline 4 & 2 & 2 & 1 & 1 & 1 & 1 & 2 & & 2 & 0 & 1 & 1 & 6 & 2 & 1 & 1 \\
\hline 0 & 1 & 2 & 1 & 1 & 1 & 3 & 1 & & 0 & 1 & 0 & 1 & 0 & 4 & 1 & 2 \\
\hline & 2 & 2 & 1 & & 2 & 3 & 0 & & 2 & 2 & 0 & & 1 & 2 & 1 & \\
\hline
\end{tabular}

Figure 5: Numbers of seeds/seedlings lost during experiment 
$\begin{array}{lllllllllllllllll}1 & 2 & 3 & 4 & 5 & 6 & 7 & 8 & 9 & 10 & 11 & 12 & 13 & 14 & 15 & 16 & 17\end{array}$ \begin{tabular}{|l|l|l|l|l|l|l|l|l|l|l|l|l|l|l|l|l|}
\hline & 2 & 0 & 1 & & 2 & 0 & 0 & & 1 & 1 & 1 & & 1 & 3 & 0 & \\
\hline
\end{tabular} \begin{tabular}{llllllllllll|l|l|l|l|l|l|l|l|} 
B & 2 & 1 & 4 & 0 & 1 & 1 & 3 & 2 & & 2 & 0 & 2 & 1 & 3 & 1 & 1 & 1 \\
\hline
\end{tabular}

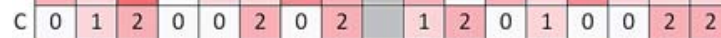
\begin{tabular}{ll|l|l|l|l|l|l|l|l|l|l|l|l|l|l|l|l|}
\hline $\mathrm{D}$ & 0 & 0 & 1 & 1 & 1 & 0 & 0 & & 2 & 1 & 1 & 2 & 3 & 0 & 2 & 1 \\
\hline & 2 & 4 & 0 & & 1 & 2 & 1 & & 3 & 1 & 3 & & 1 & 0 & 1 & \\
\hline
\end{tabular}

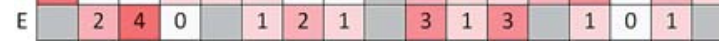

Figure 6: Numbers of seeds not grown during experiment

\begin{tabular}{l|l|l|l|l|l|l|l|l|l|l|l|l|l|l|l|l|l|}
\multicolumn{2}{c|}{1} & 2 & 3 & 4 & 5 & 6 & 7 & 8 & 9 & 10 & 11 & 12 & 13 & 14 & 15 & 16 & 17 \\
\hline A & & 25 & 21 & 25 & & 22 & 11 & 16 & & 25 & 23 & 24 & & 18 & 24 & 26 & \\
\hline B & 22 & 26 & 14 & 20 & 13 & 17 & 12 & 20 & & 21 & 22 & 22 & 24 & 24 & 26 & 17 & 24 \\
\hline C C & 17 & 17 & 18 & 18 & 21 & 20 & 12 & 14 & & 20 & 26 & 10 & 22 & 23 & 17 & 22 & 28 \\
\hline D & 25 & 27 & 15 & 18 & 17 & 29 & 10 & 19 & 16 & 15 & 22 & 27 & 16 & 26 & 27 & 22 \\
\hline E & & 13 & 14 & 22 & & 21 & 13 & 32 & & 24 & 23 & 20 & & 20 & 19 & 24 & \\
\hline
\end{tabular}

Figure 7: Average shoot lengths in $\mathrm{mm}$ on $27^{\text {th }}$ (final) day of experiment

Similarly, seeds in the areas with the lowest illumination (esp. columns 16 and 17) do not necessarily have smaller chances of growing. Apparently, the percentage of growing seeds is randomly distributed, i.e. dependent on stochastic variations of the seed quality and not on experimental parameters.

Next, the average lengths of plants (measured from the fabric to the end of the plant without stretching it) on the last day is given in Figure 7 and compared with the actual, true lengths in their fully linearized state, depicted in Figure 8. The average length, measured as mentioned above, can be measured daily to follow the growth process, while stretching the shoot to evaluate its true length may impede and possibly break the plant. Thus, our aim was to evaluate whether there is a clear correlation between both values and to show whether taking the average length without stretching is a useful measure of daily changes in plant growth.

Firstly, Figure 7 clearly shows that reduced flow rates (columns 1, 4 and 14) did not lead to reduced growth. Estimating the influence of the amount of water available for plants is not easy since the flow rate measurements (cf. Figure 4) are only valid for the highest samples per column, while the samples

\begin{tabular}{l|l|l|l|l|l|l|l|l|l|l|l|l|l|l|l|l|l|}
\multicolumn{1}{c|}{1} & 2 & 3 & 4 & 5 & 6 & 7 & 8 & 9 & 10 & 11 & 12 & 13 & 14 & 15 & 16 & 17 \\
\hline A & & 50 & 56 & 52 & & 39 & 21 & 31 & & 44 & 35 & 50 & & 69 & 33 & 38 & \\
\hline B & 40 & 47 & 27 & 39 & 15 & 64 & 31 & 42 & & 47 & 71 & 45 & 23 & 51 & 52 & 29 & 46 \\
\hline C & 55 & 37 & 57 & 54 & 39 & 44 & 32 & 33 & 54 & 50 & 41 & 28 & 54 & 32 & 65 & 46 \\
\hline D & 34 & 37 & 63 & 80 & 56 & 45 & 50 & 37 & 36 & 65 & 48 & 31 & 49 & 35 & 34 & 51 \\
\hline E & 29 & 36 & 65 & & 50 & 25 & 54 & 44 & 33 & 55 & & 51 & 58 & 53 & \\
\hline
\end{tabular}

Figure 8: Average true lengths in $\mathrm{mm}$ on $27^{\text {th }}$ (final) day of experiment at lower places can be expected to be reached by less water due to the evaporation in the upper part of the test stand. Nevertheless, an estimate of this influence will be given later on.

Next, Figure 8 does not show any correlations with illumination or irrigation. This means that the average real length does not depend on these factors. It should be noted that the light intensity was close to the light compensation point reported for other plant species of the family Brassicaceae, e.g. radish with $29 \mu \mathrm{mol}$ photons $\mathrm{m}^{-2} \mathrm{~s}^{-1}$ [21], corresponding to about $7 \mathrm{~W} / \mathrm{m}^{2}$. Below the light compensation point, respiratory $\mathrm{CO}_{2}$ release of the plant exceeds the photosynthetic $\mathrm{CO}_{2}$ assimilation and the plant fails to increase its dry mass. In the case of cress, the carbon-rich oil seed provides a carbon and energy source for extended growth which was measured in this experiment.

The quotient of true length and length measured in the experiment, not taking into account the bent stems of plants, can be regarded as a measure of the degree of bending and may be expected to be higher for plants the roots of which are either less strongly fixed inside the substrate or which are more strongly trying to grow into the direction of light. Figure 9 depicts these values. Again, while quotients vary strongly between different samples, no correlation to illumination or irrigation is visible. The offered light intensity, despite being near the light compensation point for growth, is entirely sufficient to trigger the so-called phototropism, i.e. the oriented growth of plants in the direction of incident light [22].

Finally, Figures 10 and 11 depict the correlations between the true lengths (cf. Figure 8 ) and the three experimental parameters, i.e. illumination, irrigation (only calculated for the highest sample per column) and stitch dimensions.

These point clouds clearly indicate that there is no correlation between the true lengths and illumination, while a small negative correlation between the true length and the flow rate cannot be excluded; nevertheless, the latter is not significant either.

\begin{tabular}{c|c|c|c|c|c|c|c|c|c|c|c|c|c|c|c|c|c|c|c|}
\multicolumn{2}{c}{1} & 2 & 3 & 4 & 5 & 6 & 7 & 8 & 9 & 10 & 11 & 12 & 13 & 14 & 15 & 16 & 17 \\
\hline $\mathrm{A}$ & & 2 & 2.7 & 2.1 & & 1.8 & 1.9 & 1.9 & & 1.8 & 1.5 & 2.1 & & 3.8 & 1.4 & 1.5 & \\
\hline $\mathrm{B}$ & 1.8 & 1.8 & 1.9 & 2.0 & 1.2 & 3.8 & 2.6 & 2.1 & & 2.2 & 3.2 & 2.0 & 1.0 & 2.1 & 2.0 & 1.7 & 1.9 \\
\hline $\mathrm{C}$ & 3.2 & 2.2 & 3.2 & 3.0 & 1.9 & 2.2 & 2.7 & 2.4 & & 2.7 & 1.9 & 4.1 & 1.3 & 2.3 & 1.9 & 3.0 & 1.6 \\
\hline $\mathrm{D}$ & 1.4 & 1.4 & 4.2 & 4.4 & 3.3 & 1.6 & 5.0 & 1.9 & & 2.3 & 4.3 & 2.2 & 1.1 & 3.1 & 1.3 & 1.3 & 2.3 \\
\hline $\mathrm{E}$ & & 2.2 & 2.6 & 3.0 & & 2.4 & 1.9 & 1.7 & & 1.8 & 1.4 & 2.8 & & 2.6 & 3.1 & 2.2 & \\
\hline
\end{tabular}

Figure 9: Average quotient of true lengths and experimental length on $27^{\text {th }}$ (final) day of experiment 
The large range of values given in Figure 9 also suggests that measuring the average length without stretching the plant is no reliable measure of the growth process.

Moreover, stitch dimensions do not show an influence on the true lengths either (cf. Figure 11). It should be mentioned that according to Table 1, this also means that the areal weight, fabric thickness and other parameters changing with the stitch dimension do not significantly alter the results. This finding can be explained by the konjac gum coating which is sufficient to fix most of the seeds on each textile fabric at the beginning of experiments so that the impact of the stitch dimension on the initial fixation of the seed is negligible.
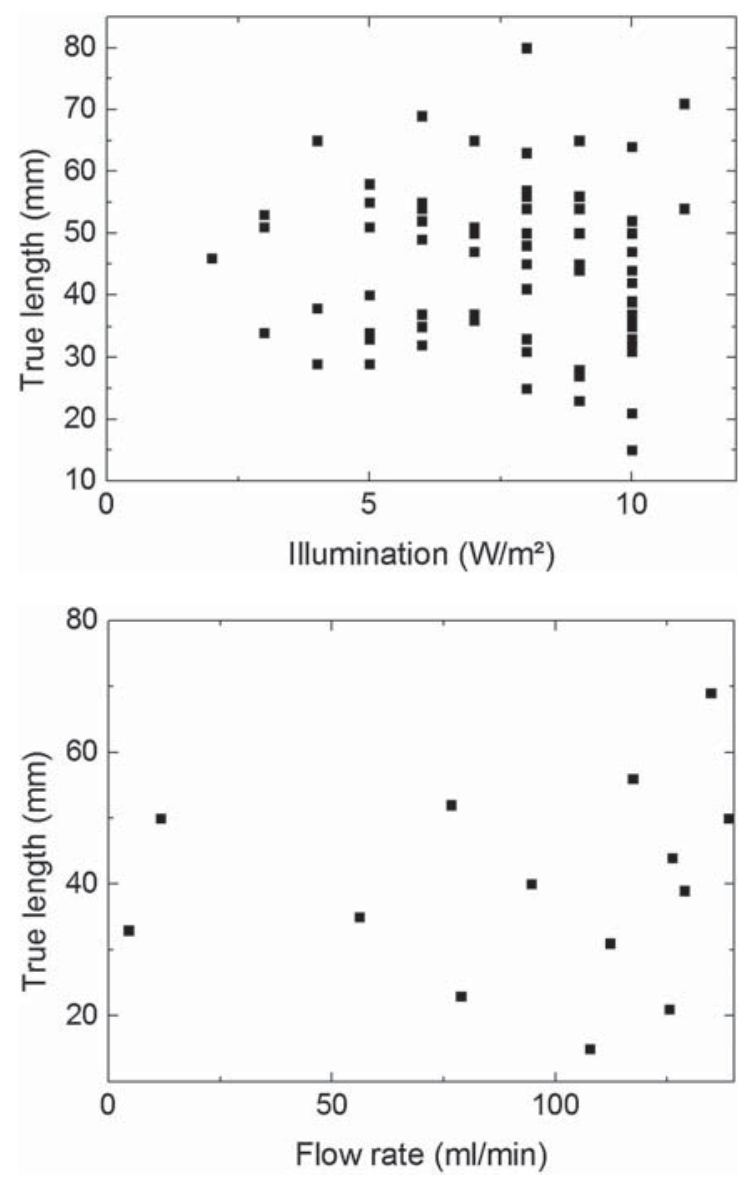

Figure 10: Dependence of true lengths on illumination (all samples) and irrigation (highest mounted samples only), measured on $27^{\text {th }}$ (final) day of experiment

This finding can be interpreted as a negligible influence of examined parameters on the growth of cress on vertically mounted textile fabrics. Nevertheless, it must be mentioned that this result can also be interpreted as the true length of a plant stem not being fully indicative of the plant growth, i.e. that other biological and biochemical parameters should be taken into account during the evaluation of the growth process of diverse plants on textile substrates. One of these possible parameters is the dry mass at the end of the experiment, which is also going to be evaluated in the forthcoming study.

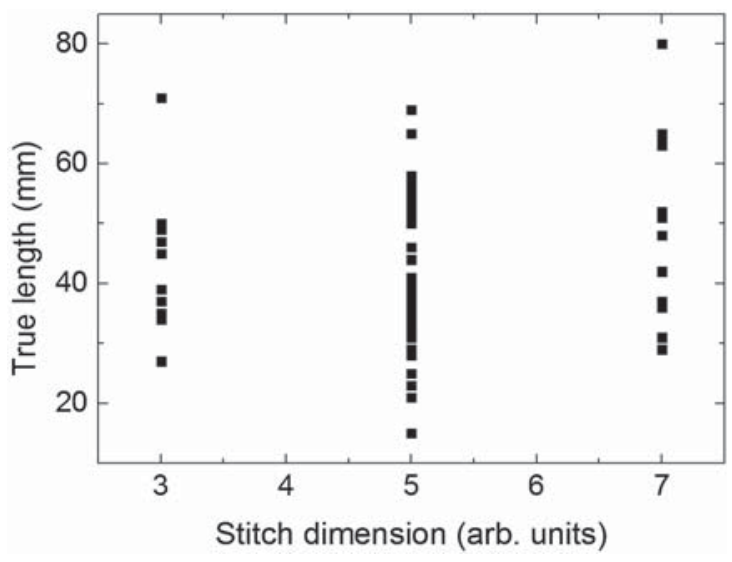

Figure 11: Dependence of true lengths on stitch dimension, measured on $27^{\text {th }}$ (final) day of experiment

\section{Conclusion and outlook}

Cress seeds were grown on vertically mounted knitted fabrics with different stitch dimensions. By varying also illumination and irrigation for overall 72 samples with 9 seeds each, no significant influence of these three parameters on the true length of cress stems was found after 27 days, whereas strong fluctuations occurred between single seeds. In addition, further studies need to involve the optimization of irrigation. It is sufficient to keep the fabrics moist and over-wetting should be avoided.

It should be mentioned that while fabric thickness, areal weight, illumination etc. did not show a substantial influence on plant growth, it cannot be excluded that a stronger modification of these parameters, e.g. by comparing finest knitted fabrics with thick plush fabrics or by illuminating far above the light compensation point, would show an influence in future investigations.

Our study shows on the one hand that it is generally possible to grow plants like cress on vertically oriented knitted fabrics, especially if combined with a 
slowly dissolving coating which fixes the seeds at the beginning of the experiment. On the other hand, further growth parameters, e.g. dry mass of plants, should also be taken into account in future experiments to avoid missing possible relevant measures for the success of plant growth. Moreover, other plants of agricultural interest which are more difficult to grow than cress, e.g. spinach, thyme or marjoram, should be examined in terms of their suitability for vertical farming.

After this proof-of-principle underlining that plant growth on textile fabrics is generally possible, future experiments could examine the possibilities to tailor the textile substrates for the requirements of selected plants. In this way, new paths get opened to a fully vertical farming technology, providing new spaces to be used for plant growth.

\section{Acknowledgments}

The project was partly funded by the Federal Ministry for Economic Affairs and Energy in the scope of the ZIM project ZF4036107 and by the HiF fund of Bielefeld University of Applied Sciences.

\section{References}

1. SCARLAT, Razvan, RUSU, Leonard, PRICOP, Floarea. Knitted agrotextiles for a sustainable agriculture. Industria Textila 2017, 68(5), 332336, doi: 10.35530/it.068.05.1413.

2. PONJIČAN, Ondrej, BAJKIN, Anđelko, DIMITRIJEVIĆ, Aleksandar, MILEUSNIC, Zoran, MIODRAGOVIĆ, Rajko. The influence of soil mulching and greenhouse covering material on the temperature distribution in lettuce production. In 39th International Symposium on Agricultural Engineering, Actual Tasks on Agricultural Engineering : book of proceedings. Zagreb : Zavod za mehanizaciju poljuprivrede, Agronomski fakultet Sveučilišta u Zagrebu, 2011, 39, pp. 393-401.

3. DE SIMONE, Serena, LOMBARDI, Fiorella Anna, PALADINI, Federica, STARACE, Giuseppe, SANNINO, Alessandro, POLLINI, Mauro. Development of antibacterial silver treatments on HDPE nets for agriculture. Journal of Applied Polymer Science, 2015, 132(11), 41623, doi: 10.1002/ app.41623.
4. REBARZ, Katarzyna, BORÓWCZAK, Franciszek, GAJ, Renata, FRIESKE, Tomasz. Effects of cover type and harvest date on yield, quality and cost-effectiveness of early potato cultivation. American Journal of Potato Research, 2015, 92(3), 359-366, doi: 10.1007/s12230-015-9441-0.

5. DAN, Maria, VISILEANU, Emilia, DUMITRESCU, Iuliana, MOCIOIU, Ana-Maria, RADULESCU, Hortensia Clara, RADULESCU, Radu, LAGUNOVSCHI, Viorica Luchian. Manufactures textile cover meant for plant protection in the cold season. In ICAMS $2010-3^{\text {rd }}$ International Conference on Advanced Materials and Systems: Proceedings. Bucharest : CERTEX, 2010, 33-38.

6. MARTIN, T., KAMAL, A., GOGO, E., SAIDI, M., DELÉTRÉ, E., BONAFOS, R., SIMON, S., NGOUAJIO, M. Repellent effect of alphacypermethrin-treated netting against Bemisia tabaci (Hemiptera: Aleyrodidae). Journal of Economic Entomology, 2014, 107(2), 684-690, doi: 10. 1603/EC12490.

7. GOGO, Elisha Otieno, SAIDI, Mwanarusi, OCHIENG, Jacob Mugwa, MARTIN, Tihbaud, BAIRD, Vance, NGOUAJIO, Mathieu. Microclimate modification and insect pest exclusion using agronet improve pod yield and quality of French bean. HortScience, 2014, 49(10), 1298-3104, doi: 10.21273/hortsci.49.10.1298.

8. MUTISYA, Stella, SAIDI, Mwanarusi, OPIYO, Arnold, NGOUAJIO, Mathieu, MARTIN, Thibaud. Synergistic effects of agronet covers and companion cropping on reducing whitefly infestation and improving yield of open fieldgrown tomatoes. Agronomy, 2016, 6(3), 42, doi: 10.3390/agronomy6030042.

9. EHRMANN, Andrea. On the possible use of textile fabrics for vertical farming. Tekstilec 2019, 62, 34-41, doi: 10.14502/tekstilec2019.62.34-41.

10. SABANTINA, Lilia, KINZEL, Franziska, HAUSER, Thomas, TÖBBER, Astrid, KLÖCKER, Michaela, DÖPKE, Christoph, BÖTTJER, Robin, WEHLAGE, Daria, RATTENHOLL, Anke, EHRMANN, Andrea. Comparative study of Pleurotus ostreatus mushroom grown on modified PAN nanofiber mats. Nanomaterials, 2019, 9(3), 475, doi: 10.3390/nano9030475.

11. HELBERG, Julia, KLÖCKER, Michaela, SABANTINA, Lilia, STORCK, Jan Lukas, BÖTTJER, Robin, BROCKHAGEN, Bennet, KINZEL, 
Franziska, RATTENHOLL, Anke, EHRMANN, Andrea. Growth of Pleurotus ostreatus on different textile materials for vertical farming. Materials 2019, 12, 2270; doi: 10.3390/ma12142270.

12. GROßERHODE, Christina, WEHLAGE, Daria, GROTHE, Timo, GRIMMELSMANN, Nils, FUCHS, Sandra, HARTMANN, Jessica, MAZUR, Patrycja, RESCHKE, Vanessa, SIEMENS, Helena, RATTENHOLL, Anke, HOMBURG, Sarah Vanessa, EHRMANN, Andrea. Investigation of microalgae growth on electrospun nanofiber mats. AIMS Bioengineering, 2017, 4(3), 376-685, doi: 10.3934/bioeng.2017.3.376.

13. AL-CHALABI, Malek. Vertical farming: Skyscraper sustainability? Sustainable Cities and Society, 2015, 18, 74-77, doi: 10.1016/j.scs. 2015. 06.003 .

14. TOUlIATOS, Dionysios, DODD, Ian, C., McAINSH, Martin. Vertical farming increases lettuce yield per unit area compared to conventional horizontal hydroponics. Food and Energy Security, 2016, 5(3), 184-191, doi: 10.1002/ fes3.83.

15. DESPOMMIER, Dickson. Farming up the city: the rise of urban vertical farms. Trends in Biotechnology, 2013, 31(7), 388-389.

16. JANUSZKIEWICZ, Krystyna, JARMUSZ, Malgorzata. Envisioning urban farming for food security during the climate change era. Vertical farm within highly urbanized areas. IOP Conference Series: Materials Science and Engineering, 2017, 245, 052094, doi: 10.1088/1757-899$\mathrm{x} / 245 / 5 / 052094$.
17. PINSTRUP-ANDERSON, Per. Is it time to take vertical indoor farming seriously? Global Food Security, 2018, 17, 233-235, doi: 10.1016/j.gfs. 2017.09.002.

18. ZHU, Fan. Modification of konjac glucomannan for diverse applications. Food Chemistry, 2018, 256, 419-426, doi: 10.1016/j.foodchem. 2018. 02.151 .

19. ZHANG, Hui, CUI, Sisi, HUAXIN, L. V., PEI, Xuejing, GAO, Meijiao, CHEN, Sainan, HU, Junli, ZHOU, Yifa, LIU, Yichun. A crosslinking strategy to make neutral polysaccharide nanofibers robust and biocompatible: With konjac glucomannan as an example. Carbohydrate Polymers, 2019, 215, 130-136, doi: 10.1016/j. carbpol.2019.03.075.

20. HENNINGS, Detlef. Leitfaden Elektrische Energie im Hochbau. Darmstadt : Institut Wohnen und Umwelt, 2000 [online], [cited 4. 9. 2019]. Available on World Wide Web: <https://www. iwu.de/fileadmin/user_upload/dateien/energie/ strom/lee-text.pdf $>$.

21. OH, Soonja, MOON, Kyung Hwan, SONG, Eun Young, SON, In-Chang, KOH. Photosynthesis of Chinese cabbage and radish in response to rising leaf temperature during spring. Horticulture, Environment and Biotechnology, 2015, 56(2), 159-166, doi: 10.1007/s13580015- 0122-1.

22. CHRISTIE, John, M. Phototropin blue-light receptors. Annual Review of Plant Biology, 2007, 58(1), 21-45, doi: 10.1146/annurev.arplant.58. 032806.103951 . 